The immediate source of attraction possessed by the flower for its feathered visitan!s lies, I think, in the small insects which resort to it, and not, at any rate usually, in their furnishing any nectareous secretion which is palatable to the birds. For if the latter visited the blossoms for the sake of the nectar they would be perfectly acouainted by experience with its situation and make no delay in going straight to it, whereas the habit of the sun-birds and the flower-peckers also is rather to hover on riloidly-vibrating wings a few inches in front of the opening of a bjossom, as if prying into its recesses in search of food, before thrusting their beaks into the corolla; and often afrer thus examining a flower they fly off to another without touching it at all, having apparently satisfied themselves that the first one contained no prey for them.

N. Mindanao, July 23

\section{Heat Phenomena and Muscular Action}

ON reading the article which appeared in NaTuRE, vol, xvi. p. $45 \mathrm{I}$, on the heat phenomena accompanying muscular action, it has occurred to me to send the following problem which is akin to the subject.

If a man does work (say lifts a weight), the principle of the conservation of energy teaches us that the potential energy-the work done-(weight lifted) is at the expense of the man as a magazine of force, in fact that "virtue has gone out of him." Now suppose a man lifts say a ton of bricks and deposits the bricks one by one on the top of a wall six feet high, we can exactly estimate the amount of work done, the energy rendered potential and external, and if we knew also the extra amount of heat radiated or otherwise carried off from his body-as most probably the work would raise his temperature-we could exactly measure the amount of energy the lifting of the brick cost him.

Now suppose another man were to lift the bricks from the top of the wall and deposit them gently-i,e, without concussionon the ground, it is eviclent that there is a ccrtain amount of potential energy disappearing, in fact that there is work being absorbed by the man, of course appearing in some other form, i) ut the question is how? This second man's work is of course in ene sense work, but in the sense of producing exiernal, potential, or kinetic energy, is not so, unless, perhaps, in heat.

Strangely enough it follows that lifting down the brick ought to make the man either radiate heat more, waste tissue lcse, digest food less, or in some other way account for the energy ahsorbed by him.

Generally I think the conversion of force by olstruction is not always so clearly traced as it might be ; in friction it is clear, as also in the compression of elastic bodies, but in the instance above, as also in the throttling of steam, it is not so clear.

\section{A. R. MOLISON}

Does Sunshine Extinguish Fire?

I. READ Mr. Tomlinson's paper (NATURE, vol. xvi. p. 36r) near the time of its delivery, and was struck with the inconclusive character of his experiments. What he attempted to obtain was the condition of combustion in sunshine and combustion in darkness, cateris paribus. But he left the cateris paribus entirely out of the experiment, and actually used a dark cubbard (I believe this is good spelling etymologically and phonetically), into which there was no free influx of atmospheric air. Naturally his candles burnt with inferior combustion there. I have for years together burnt Newcastle coal, and ro other; and for years together burnt Susth Staffordshire coal, and no other; and I say that sunshine puts out a sea-coal fire and not a S.S. fire. The reason of this is, I apprehend, not far to seek. In the Midlands it is the practice to keep a fire alive by a raker, or gathercoal. It would be quite useless to attempt to do this with a sea-coal fire, which goes out in a short time unless the cakes of coal be broken up; in a word, one has to watch a sea-coal fire; and it must be in every Londoner's experience, that such a fire is apt to elude one at the last faint gleam from over reckless poking. Now, if the sun is shining on the coal, that last faint gleam is invisible, and the fire gces out as a matter of course. Sunshine puts out a sea-coal fire by insidiously eclipsing the warning glimmer of its expiring embers. This, at least, is a vera causa. A priori I should say that combustion would be less rapid in air rarefied by sunlight than in air deprived of it; but I do not believe sunshine extinguishes a coal fre in any other way than that I have described.

C. M. INGLEBY

Folkestone

\section{OUR ASTRONOMICAL COLUMN}

The ApProaching Opposífion of Iris.-The opposition of this minor planet in the present autumn affords another favourable opportunity of determining the amount of solar parallax on the method already successfully applied by Prof. Galle, of Breslau, in the case of Flora. The Berliner astronomisches Fahrbuch for I 879 contains a rough ephemeris of Iris for every twentieth day of the year, but this being insufficient for the purpose in view, we subjoin places calculated from Prof. Brünnow's tables of the planet, on the approximate formulæ explained in his introduction; the error of the tables being very sensible at the present time, nothing would have been gained by calculating in the accurate form. For the sake of brevity the planet's positions are given for every fourth day only, but they will be readily interpolated for the intermediate dates.

\begin{tabular}{|c|c|c|c|c|c|c|c|c|c|}
\hline \multirow[b]{3}{*}{ Oct. } & \multirow[b]{3}{*}{8} & \multirow{2}{*}{\multicolumn{2}{|c|}{$\begin{array}{c}\text { Right } \\
\text { Ascension. }\end{array}$}} & \multirow{2}{*}{\multicolumn{2}{|c|}{$\begin{array}{c}\text { North } \\
\text { Declination. }\end{array}$}} & \multirow{3}{*}{\multicolumn{2}{|c|}{$\begin{array}{c}\text { Distance } \\
\text { from the } \\
\text { Farih. } \\
\text { I.0034 }\end{array}$}} & \multirow{3}{*}{\multicolumn{2}{|c|}{$\begin{array}{l}\text { Distance } \\
\text { from tly } \\
\text { Sun. } \\
\text { r } 8350\end{array}$}} \\
\hline & & & & & & & & & \\
\hline & & $\begin{array}{l}\text { h. m. } \\
356\end{array}$ & s. & $\begin{array}{r}0 \\
27\end{array}$ & & & & & \\
\hline 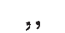 & I2 & $\therefore 356$ & $5^{\circ}$ & & 33 & $\cdots$ & 0.9769 & & \\
\hline & I 6 & ‥ 356 & 55 & ... 26 & 57.8 & $\ldots$ & 26 & & $\mathbf{I} \cdot 83$ \\
\hline , & 20 & ․ 356 & 20 & ... 26 & 48.9 & $\cdots$ & $0^{\circ}$ & & \\
\hline , & 24 & 355 & 8 & .. 26 & $36 \cdot 5$ & .. & 1 & $\ldots$ & I $\delta_{3}$ \\
\hline & 28 & 353 & 20 & ... 26 & 20.5 & $\ldots$ & 44 & & \\
\hline 07 & I & 350 & $5^{8}$ & $\ldots 26$ & 0.9 & $\cdots$ & o. 8808 & $\ldots$ & I 8376 \\
\hline & 5 & . 348 & 8 & ... 25 & 37.8 & $\ldots$ & o 8704 & & \\
\hline & 9 & ․ 344 & 57 & ... 25 & II & $\cdots$ & 0.8 & & $I \cdot S_{4}$ \\
\hline & 13 & . $34 \mathrm{I}$ & $3^{2}$ & .. 24 & $4^{2}$ & $\ldots$ & & & \\
\hline & I7 & $\cdots 33^{8}$ & I & ... 24 & $11 \cdot 5$ & .. & 0. & .. & I 8 \\
\hline & 2 I & 334 & $3 I$ & .. 23 & $3^{8 \cdot 7}$ & . & & & \\
\hline & 25 & 331 & 9 & $\ldots 23$ & & $\cdots$ & & $\ldots$ & $I \cdot S$ \\
\hline & 29 & 328 & 2 & & $3 x \cdot 2$ & & 0.8819 & & \\
\hline ec. & 3 & ․ 325 & I7 & $\ldots 2 \mathrm{I}$ & $58 \cdot 1$ & . & 0.8955 & & $I \cdot 85$ \\
\hline & 7 & ․ 322 & 58 & $\ldots$ & 20 & . & & & \\
\hline & I I & ․ $32 \mathrm{I}$ & I I & .. 20 & $5^{6}$ & & & & $I \cdot$ \\
\hline
\end{tabular}

Iris will be in perihelion October 1477, G.M.T., and nearest to the earth on November I 5, her distance at this time being 0.859 (the earth's mean distance from the sun being taken as unity). Her intensity of light may be expected to rather exceed that of a star of the seventh magnitude, $6 \cdot 8 \mathrm{~m}$. according to the Berliner fahrbuch.

THE OUTiR SATEleite OF MARs.--This object is still under observation at the Observatory of Paris. It was also measured again by $\mathrm{Mr}$. Common, of Ealing, with his I 8-inch silver-on-glass reflector on September 24 , the angle calculated from the elements which have been given in this column differing from the observed angle $-4^{\circ}$. An observation on September 13, by M. Borrelly at Marseilles, presumed to apply to the satellite, must refer to a faint star, the satellite at the time being in the opposite quadrant.

Binary STARs.-Dr. Doberck, of Markree Observatory, continues his investigations on the orbits of the revolving double stars. In No, 2, I56 of the Astronomische Nachrichten he has given provisional elements of $\Sigma i 768$ and $\Sigma$ 3I2I, the latter of which appears to be an object of special interest from the shortness of the period of revolution, which hardly exceeds that of the well-known binary, $\zeta$ Herculis. Also elements of $\Sigma$ 3062, a star which was the subject of a pretty complete calculation by Dr. Schur in 1867. The results of the tivo discussions are as follow :-

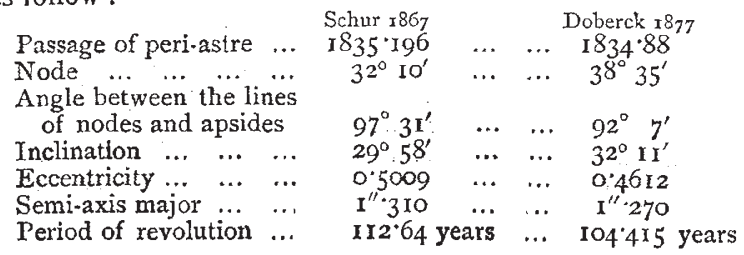

